\title{
What species of owlflies (Neuroptera: Ascalaphidae), an extinct family in Poland, have occurred in Poland in the past?
}

\author{
Roland DoBosz \\ Department of The Natural History, Upper Silesian Museum, PI. Sobieskiego 2, 41-902 Bytom, Poland \\ e-mail:dobosz@muzeum.bytom.pl
}

\begin{abstract}
Literature data on Ascalaphidae in Poland are critically discussed. Libelloides macaronius has never been found in the present-day territory of Poland. Libelloides coccajus most likely occurred in Poland at the end of the 18th century. Evidence for this statement comprises a drawing and a note in a manuscript of Charles de Perthées from $1802-1803$.
\end{abstract}

Key words: Neuroptera, Ascalaphidae, Libelloides coccajus, Libelloides macaronius, Poland, distribution, extinet species.

The intensive research on the Neuropterida carried out in Poland up to the end of 1980's revealed several species new to the Polish fauna. Nevertheless, most of the faunistic data available come from papers written 50 or even 100 years ago. Even if the data from papers published after the end of the Second World War are not to be doubted, the information from earlier times is difficult to verify. The reasons are: lack of voucher specimens and unclear data on specimens mentioned in the papers or presented on the labels. These problems mounted enormously following changes to the borders of Poland due to political and historical changes. Therefore, besides a revision of the scarce specimens and collections available, a review of the bibliographical data presented in this paper, both Polish and non-Polish, must be undertaken before the number and a list of species recorded within borders of Poland up to the Second World War can be presented. Such data were often presented as very poor and general, with numerous misspellings and language errors, which in some cases make the interpretation very difficult, or even impossible.

The limits of distribution of several species of plants and animals are known to be in the area of Poland. Therefore such faunistic data are very important for zoogeographical analyses. Special attention must be given to the topographic data comprised in the old, historical collections, which are frequently invaluable for the interpretation of transformations of the flora and fauna of the Western Palaearctic over the last few centuries. Dynamic changes of climatic and biotic conditions resulted in numerous temporary migrations of numerous organisms, insects in particular.

The most recent list of Neuropterida of Poland (Czechowska 2007) contains erroneous data about the probable presence in Poland of Libelloides macaronius (Scopoli, 1763) of the family Ascalaphidae. This data was based on the report of Pongrácz (1919). In the materials regarding the status of neuropteroid species of Poland Pongrácz pointed out that "... Ohne nähere Fundorte. In Galizien vereinzelt, selen...", i.e. rarely in Galicia. Ascalaphus kolyvanensis (Laxmann, 1770), a synonym of L. macaronius, had been recorded by Pongrácz. These times, the term "Galizien" referred to an area that is now outside of the borders of Poland. In all formerly published papers and reports, citations of the localities of this species do not refer to 
sites within the current borders of Poland; however, some localities are close to these borders. The most interesting data, in terms of knowledge of Polish fauna, are the localities given in the Red Data Books of the former Soviet Union and Ukraine (Kochetova 1985; Ermolenko 1994). Some of these localities are found close to the south-eastern border of Poland. The localities of this species are poorly documented in Slovakia, or doubtful (Zelený 1992, 2005; Jedlička 2001). The Red Data Books are by nature compendia rather than critical analyses of scientific reports. Zakharenko (1994), in a critical review of the neuropterofauna of Ukraine, pointed out that the localities of $L$. macaronius in the western part of Ukraine currently do not exist.

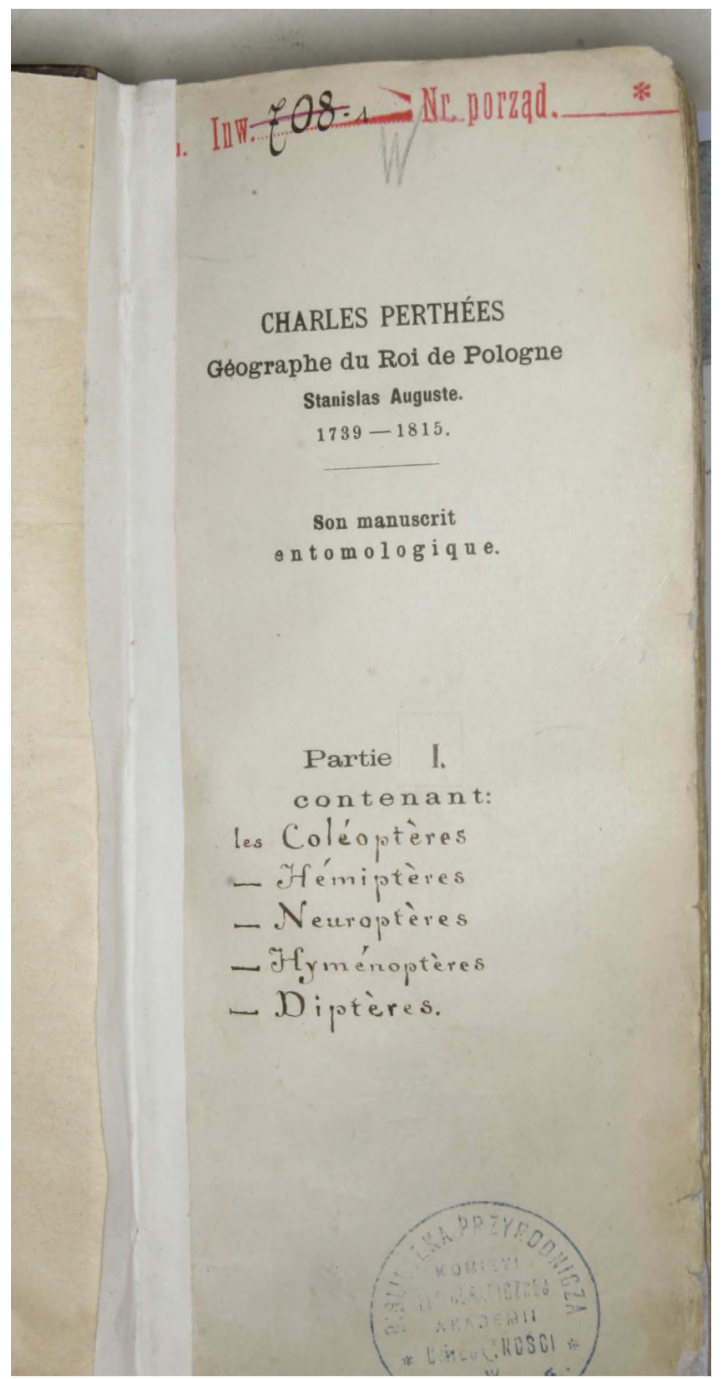

Fig. 1. Title page of the first volume of the manuscript of Charles de Perthees (thanks of the courtesy of the Library of Institute of Systematics and Evolution of Animals, Polish Academy of Sciences, Kraków). with a few drawings of Neuropterida, the details of the collection sites were given. Charles de Perthées made mistakes in the identification of some species, but his detailed drawings are the area of Poland is Libelloides coccajus (Denis et Schiffermüller, 1775). At present, this species is relatively widely distributed (Aspöck et al. 2001). The localities of this species that are currently closest to Poland are known in Germany and Czech Republic (Röhricht \& Tröger 1998, Zeleny 2005), while the presence of this species in Slovakia is doubtful (Jedlička 2001; Jedlička et al. 2004; Zeleny 1977, 1992).

One of the oldest and most comprehensive elaborations containing faunistic data from Poland is the manuscript of Prince Józef Poniatowski's court cartographer - Charles de Perthées (1739-1815). This researcher, endowed with impressive drawing abilities, in addition to insect collecting, presented notes on numerous species enriched with perfectly detailed drawings. In numerous cases, thanks to his drawings, we have evidence for the presence of particular species, species of particular interest for the study of the origins of Polish fauna (Pawlowski 1991). Unfortunately, his rich collection disappeared or was destroyed, and its fate has remained unclear (Pawlowski 2003). The history of the destroyed collections and the nine preserved volumes of the manuscript has been stormy and particularly interesting. This story was described in detail by Pawłowski (2003, 2005). For neuropterologists, the first volume (Fig. 1) is the most interesting. It was prepared in the years 1802-1803, in which together 
unusual perfect documentation of the morphology of the insects, and it is easier to identify the species based on these drawings than based on the imperfect description. Some groups of insects presented by Perthées were described and discussed in a more detailed manner. The Neuropterida were rarely mentioned, but the descriptions included that of Ascalaphus (recently Libelloides, see Pawłowski 1991), very important for the knowledge of neuropterofauna of Poland, and a general discussion of the order (Pawłowski 2003). The first species mentioned is unusual for the Polish fauna of owlflies. It was named Ascalaphus barbarus. Ascalaphus barbarus is now a North African species (typus generis of Ascalaphus) with transparent wings. It is different from the species of Libelloides with coloured wings, but at the turn of the 19th century the name Ascalaphus barbarus was used for European species with coloured wings different from Libelloides coccajus (Pantaleoni \& Letardi 2002) or for the real L. coccajus. On the other hand, a comparison of the drawing from de Perthées with drawings of Ascalaphidae species known from Central Europe, will exclude L. macaronius, the most probable species for the Polish fauna. The characteristic black markings at the base of the hind wings doubtless indicate the second species supposed to be present in Poland, i.e. L. coccajus. The more detailed data on the date and place of collection of the specimens are not exhaustive. Fortunately, together the drawing of the specimen of 'Ascalaphus barbarus' is accompanied with a relatively long note (Fig. 2). It is written, as most of the manuscript, in poor French, with numerous abbreviations and mistakes, in numerous cases in Polish.

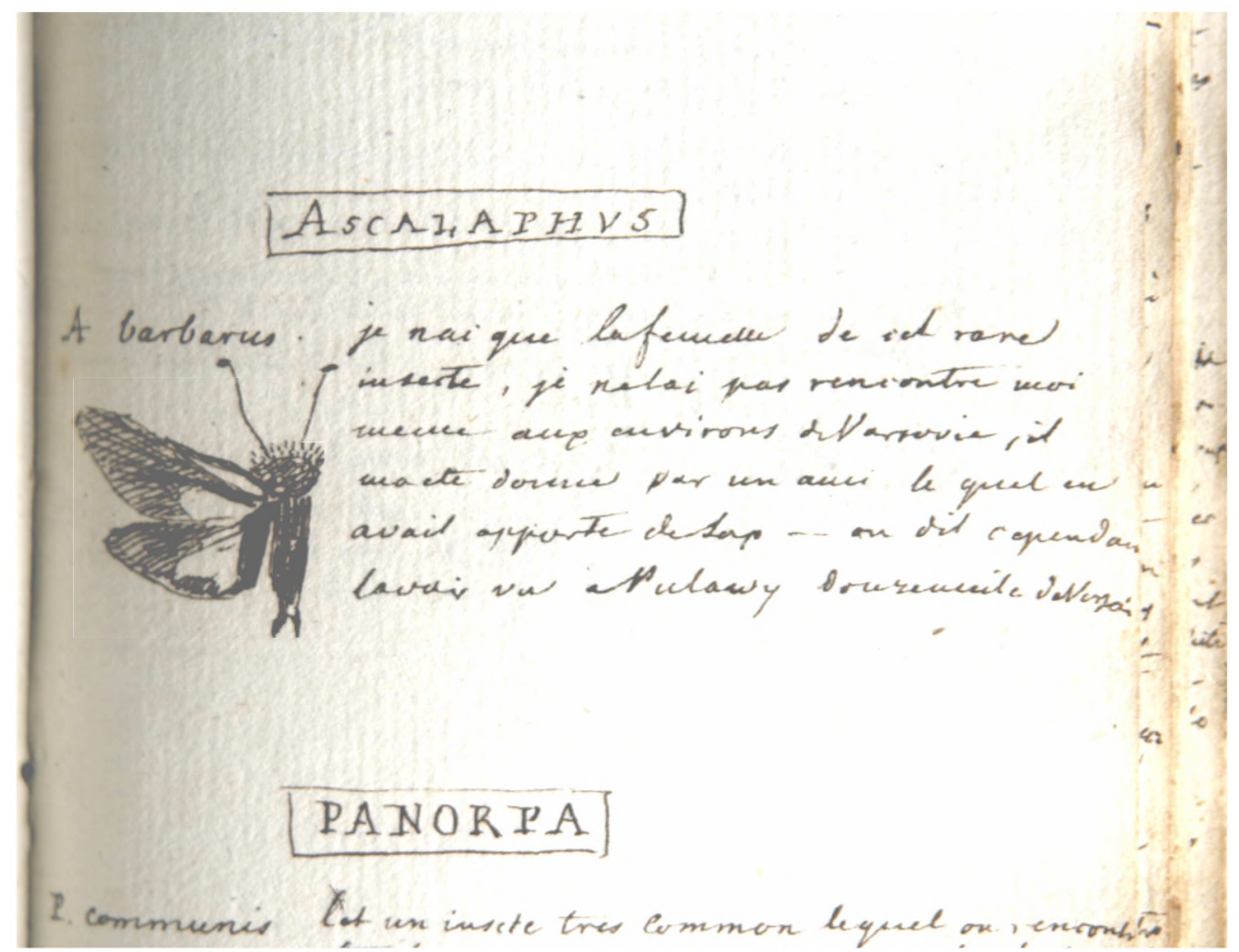

Fig. 2. Drawing of 'Ascalaphus barbarus' with a note (page 214 from the first volume of Charles de Perthées manuscript). Courtesy of the Library of Institute of Systematics and Evolution of Animals, Polish Academy of Sciences, Kraków. 
Below is the free translation by Professor Jerzy Pawlowski of the original text:

"Ascalaphus barbarus - I have only a female of this rare insect. I did not find it myself in the vicinity of Warsaw. The specimen was offered to me by one of the friends, who collected [it] in the vicinity of Pulawy, thirty miles from Warsaw".

Considering the recent distributional pattern of this species in Europe, the data from Poland collected at the turn of the 19th century are surprising. On the other hand, taking into consideration the climatic changes and examples from the other groups of insects, such fluctuation of the range is probable and possible. It could be stated with high probability that the limit of range of this species was once in Poland, maybe related to the habitats of the Vistula river valley. Collecting insects in central Poland to its southern parts, Charles de Perthées found numerous interesting species, with limits distinctly shifted now, e.g. Scarabaeus sacer L. (Coleoptera: Scarabaeidae), Purpuricenus budensis (Gotz) (Coleoptera: Cerambycidae). He collected in the vicinities of Warsaw such species as: Mantis religiosa (L.) - Mantodea, Pericalia matronula (L.), Parnassius mnemosyne (L.) and Parnassius apollo (L.) - Lepidoptera, whose current ranges are distinctly more southwards.

One of the reasons for such shifts of ranges was climatic changes. The turn of the 19th century was a time of a distinct decrease in annual temperatures in most of Europe, especially in Central Europe. An example of such changes is reports of freezing of the Baltic Sea during a dozen or so years. Very probably, changes of limits of numerous species took place at that time, especially those with narrow ecological tolerance, particularly thermal tolerance. Particularly distinct and dynamic changes could have taken place in Central Europe (Pawlowski 1991). Of course, we cannot also exclude the role of increasing anthropopression and the associated degradation of natural habitats.

\section{CONCLUSIONS}

The results of the investigations proved that at present there are no representatives of Ascalaphidae in Poland. There is no doubt that in the past $L$. coccajus was present in the area of Poland. Anyway, we have no data to confirm the presence of L. macaronius within the present borders of Poland in the past and now.

\section{ACKNOWLEDGEMENTS}

I wish to thank Professor Jerzy Pawlowski for the translation and interpretation of the text from the manuscript by Charles de Perthées.

\section{REFERENCES}

ASPÖCK H., HÖLZEL H. \& ASPÖCK U. 2001. Kommentierter Katalog der Neuropterida (Insecta: Raphidioptera, Megaloptera, Neuroptera) der Westpaläarktis. Denisia 2: 1-606.

CzechowsKa W. 2007. Sieciarki wlaściwe Neuroptera. In: Bogdanowicz W., Chudzicka E., PILIPIUK I. \& SKIBnísKa E, (eds), Fauna of Poland - Characteristics and checklist of species. Vol 2, pp. 279-292. Muzeum i Institytut Zoologii PAN, Warszawa, pp. 505.

ERMOLENKO V. M. 1994. Ascalaphus macaronius (Scopoli, 1763). In: SHCHERBAK, M. M. (ed.), Red Data Book of Ukraine. Animal kingdom. p. 107. Ukrainian encyclopedia, Kyiv, pp. 464.

JEDLIČKA L. 2001. Red (Ecosozological) List of Neuroptera of Slovakia. In: BALÁž, D. MARHOLD K., URBAN P. (eds), Red List of Plants and Animals of Slovakia. pp. 108-109. Ochrana Prírody, Banská Bystrica, Suppl. 20, pp. 160.

JEDLIČKA L., ŠEVČKK J \& VDLIČKA L. 2004. Checklist of Neuroptera of Slovakia and the Czech Republik. Biologia, Bratislava, 59, Suppl.15, pp. 59-67.

Kochetova N. I. 1985. Ascalaphus macaronius (Scopoli, 1763). In: BoroDIN, A. M., et al. (eds), Krasnaya kniga SSSR. Red Data Book of the USSR. p. 278. Moscow, vol. 1, pp. 390.

PANTALEONI R. A. \& LETARDI A. 2002. What is the real name of the Italian ascalaphid? In: SZIRAKI G. (ed.), Neuropterology 2000. Proceedings of the Seventh International Symposium on Neuropterology (6-9 August 2000, Budapest, Hungary). pp. 253-264. Acta Zoologica Academiae Scientiarum Hungaricae, 48, Suppl. 2, pp. 430. 
PAWŁowsKi J. 1991. 2.4.5. Przemiany fauny od pleniglacjału do czasów wspólczesnych. In: STARKEL L. (ed.), Geografia Polski. Środowisko przyrodnicze, pp. 159-177. PWN, Warszawa, pp. 670.

PAWŁOWSKI J. 2003. Wstępna ocena działalności entomologicznej Karola Perthéesa. In: PAWŁowsKi J. (ed.), Karol Perthées (1739-1815) kartograf Pierwszej Rzeczypospolitej i entomolog, pp. 193-260. Warszawa, pp. 342.

PAWŁowsKi J. 2005. Rękopisy entomologiczne Karola Perthéesa w Bibliotece Instytutu Systematyki i Ewolucji Zwierząt PAN w Krakowie w 110 rocznicę ich pozyskania. Rocznik Biblioteki Naukowej PAU i PAN w Krakowie 50: 167-180.

PONGRACZ A. 1919. Beiträge zur Pseudoneuropteren- und Neuropterenfauna Polens. Annales Musei Nationalis Hungarici 17: 161-177.

RÖHRICHT W. \& TRÖger E. J. 1998. Rote Liste der Netzflügler (Neuropteroidea). In: BiNOT M., Bless R., BOYE P., GRUTTKE H. \& PRETSCHER P. (eds), Rote Liste gefährdeter Tiere Deutschlands, pp. 231-234. Schriftenreiche für Landschaftspflege und Naturschutz, Bonn-Bad Godesberg, 55, pp. 434.

ZAKHARENKO A. V. 1994. Rare and extinct species of lacewings (Insecta, Neuroptera) of the fauna of Ukraine. Izvestiya Kharkovskogo Entomologiecheskogo Obshestva, 2 (2): 101-104.

ZELENÝ J. 1977. Planipennia (Neuroptera). In: DLABOLA J. (ed.), Check list 1 - Enumeratio Insectorum Bohemoslovakiae. Acta Entomologica Bohemoslovaca 68: 167-184.

ZELENÝ J. 1992. Lacewings (Neuroptera). In: ŠKAPEC L. (ed.), Cervená kniha ohrožených a vzácných druhu rostlin a živocichu CSFR 3. Bezobratlí. Red book of endangered and rare species and plants of Czechoslovak Federal Republik. 3. Invertebrates. pp. 80-82. Príroda Bratislava, pp. 155.

ZELENÝ J. 2005. Neuroptera (Lacewings)] pp. 163-165. - In: FARKAČ J., KRÁL D. ŠKOPIK M. (eds), Red list of threatened species in the Czech Republic. Invertebrates, pp. 163-165. Agentura ochrany prírody a krajiny ČR, Praha, 760 pp. [In Czech with English text]

\section{STRESZCZENIE}

\section{[Jakie gatunki z żupalkowatych (Neuroptera: Ascalaphidae), zaniklej w Polsce rodziny, występowaly u nas w przeszlości?]}

Autor krytycznie analizuje dane literaturowe dotyczące występowania na obszarze współczesnej Polski dwóch gatunków sieciarek z rodziny żupałkowatych (Ascalaphidae) Libelloides macaronius (Scopoli, 1763) i Libelloides coccajus (Denis et Schiffermüller, 1775).

W opublikowanym w ostatnich latach wykazie owadów siatkoskrzydlych (Czechowska 2007) znalazla się informacja o prawdopodobnym występowaniu na terenie Polski Libelloides macaronius. Podstawą do wlączenia tego gatunku w skład fauny Polski byla praca Pongrácz'a (1919). Autor ten w swoim przyczynku do znajomości owadów siatkoskrzydlych Polski podaje informację o występowaniu tego gatunku w Galicji. Termin Galicja dotyczył w znacznej części obszaru znajdującego się poza wspólczesnymi granicami naszego kraju. We wszystkich wcześniejszych pracach (cytowanych przez Pongrácza) stanowiska tego gatunku znajdują się poza terytorium obecnej Polski, choć niektóre znajdują się stosunkowo blisko naszych granic. Stanowiska te nie zostaly współcześnie potwierdzone (Zakharenko 1994).

Jest natomiast wielce prawdopodobne, że w Polsce występował pod koniec XVIII wieku Libelloides coccajus. Świadczą o tym notatka i rysunek zamieszczony w manuskrypcie nadwornego kartografa Księcia Józefa Poniatowskiego - Edmunda Perthéesa. Współczesne stanowiska tego gatunku, najbliżej naszych granic, znajdują się w Niemczech i Czechach (Röhricht \& Tröger 1998, Zeleny 2005). 